\title{
Deinococcus aquatilis sp. nov., isolated from water
}

Correspondence
Peter Kämpfer
peter.kaempfer@
umwelt.uni-giessen.de

At present, the genus Deinococcus comprises more than 30 species. The taxonomy of the genus has been described extensively (Suresh et al., 2004; Hirsch et al., 2004; Ferreira et al., 1997; Rainey et al., 1997, 2005), and the number of species is still growing (Asker et al., 2009; Callegan et al., 2008; de Groot et al., 2005; Lai et al., 2006; Rainey et al., 2007; Shashidhar \& Bandekar, 2006; Zhang et al., 2007). Several novel Deinococcus strains have been isolated and well characterized from soils, including desert soil, foods, faeces and dust, with additional data on their extreme resistance to $\mathrm{UV}$ and gamma radiation and desiccation.

A pale-pink-pigmented bacterium was isolated from industry water on nutrient agar. This strain (CCUG $53370^{\mathrm{T}}$ ) was maintained and subcultured on nutrient agar at $30{ }^{\circ} \mathrm{C}$ for $48 \mathrm{~h}$ and subsequently investigated for $16 \mathrm{~S}$ rRNA gene sequence, fatty acid methyl ester composition of whole-cell hydrolysates, respiratory quinones, polar lipids, polyamines and further phenotypic characteristics.

The GenBank/EMBL/DDBJ accession number for the 16S rRNA gene sequence of strain CCUG $53370^{\top}$ is AM940971.

Fatty acid profiles of strain CCUG $53370^{\top}$ and selected relatives in the genus Deinococcus are available as supplementary material with the online version of this paper.
Cultural and morphological characteristics were observed on R2A agar (Oxoid). Gram-staining was performed as described by Gerhardt et al. (1994). Cell morphology was observed under a Zeiss light microscope at $\times 1000$ magnification, with cells grown for 3 days at $28{ }^{\circ} \mathrm{C}$ on R2A.

Strain CCUG $53370^{\mathrm{T}}$ stained Gram-positive and formed visible (about $2 \mathrm{~mm}$ ) pale-pink colonies within $48 \mathrm{~h}$ at $30{ }^{\circ} \mathrm{C}$. No growth was observed above $45{ }^{\circ} \mathrm{C}$. The colonies were translucent and shiny with entire edges. Oxidase activity was tested using oxidase reagent (bioMérieux) according to the instructions of the manufacturer. Strain CCUG $53370^{\mathrm{T}}$ was oxidase-positive and non-motile and consisted of non-spore-forming rods. CCUG $53370^{\mathrm{T}}$ was able to grow well on nutrient agar and tryptone soy agar. Good growth was observed under alkaline conditions up to $\mathrm{pH} 11$.

UV radiation resistance was tested as described by Hirsch et al. (2004). The strain showed high UV resistance in comparison with the control strain Escherichia coli K-12 (data not shown).

Physiological characterization and additional biochemical tests were performed according to the methods described by Kämpfer et al. (1991). Results are given in the species description. Strain CCUG $53370^{\mathrm{T}}$ was unable to utilize 
L-arabinose, lactose, trehalose, D-xylose, D-mannose, melibiose or D-sorbitol and utilized $\mathrm{N}$-acetyl-D-glucosamine weakly; in contrast, D. ficus CC-FR2- $10^{\mathrm{T}}$ utilized all of these compounds (Lai et al., 2006).

The fatty acid pattern (determined using the method described by Kämpfer \& Kroppenstedt, 1996) for strain CCUG $53370^{\mathrm{T}}$ is shown in Supplementary Table S1 (available in IJSEM Online) in comparison with some representative Deinococcus species. The organism showed a profile typical of the genus Deinococcus.

Respiratory quinones, polar lipids and polyamines were determined after cultivation of CCUG $53370^{\mathrm{T}}$ in a medium containing the following $\left(\mathrm{g} \mathrm{l}^{-1}\right)$ : casein peptone (3), yeast extract (3), D-glucose $(0.5)$, sodium pyruvate $(0.3)$ and magnesium sulfate $(0.024)$. Polar lipids were extracted and analysed by two-dimensional TLC according to Tindall (1990a, b) and Altenburger et al. (1996). Like members of other Deinococcus species (Embley et al., 1987; Suresh et al., 2004; Ferreira et al., 1997), strain CCUG $53370^{\mathrm{T}}$ displayed a complex profile consisting of different unidentified glycolipids and polar lipids, two unknown phospholipids and three unknown phosphoglycolipids (Fig. 1). It shared with other deinococci a predominant phosphoglycolipid, which was identified in Deinococcus radiodurans as $2^{\prime}-\mathrm{O}$ (1,2-diacyl-sn-glycero-3-phospho)-3' - $\mathrm{O}$-( $\alpha$-galactosyl)- $N$ -

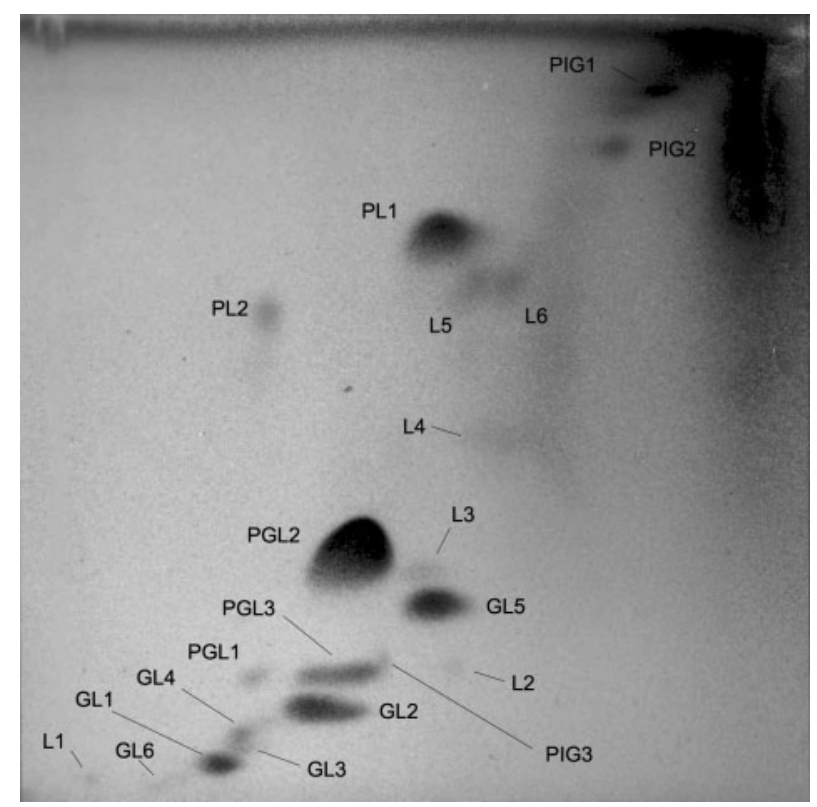

Fig. 1. Polar lipid profile of strain CCUG $53370^{\top}$. L1-L6, Unidentified polar lipids; GL1-GL5, unidentified glycolipids; PGL1-PGL3, unidentified phosphoglycolipids; PL1, PL2, unidentified phospholipids; PIG1-PIG3, brick-red pigments. Polar lipids L4, L5, L6 and PL2 (probably corresponding to L2 of D. ficus) were detected after $\alpha$-naphthol staining but specific colour development was not observed and hence they are not designated glycolipids. GL1 actually represents two $\alpha$-naphthol spots that are not distinguishable in the image.
D-glyceroyl alkylamine (Anderson \& Hansen, 1985). Certain other lipids exhibiting similar chromatographic and staining behaviour might have been detected in other deinococci. Embley et al. (1987) reported the presence of two lipids that probably correspond to GL2 and PGL3 (Fig. 1) in four strains of D. radiodurans (D10, D11, D12 and D13), two strains of Deinococcus proteolyticus (D3 and D5), a strain of Deinococcus radiophilus (D16) and two strains of Deinococcus radiopugnans (D17 ${ }^{\mathrm{T}}$ and $\left.\mathrm{D} 18\right)$. Corresponding lipids were detected in D. radiodurans DSM $20539^{\mathrm{T}}$ and Deinococcus murrayi AG-3a ${ }^{\mathrm{T}}$ (Ferreira et al., 1997), and counterparts of GL5 (Fig. 1) may have been found in D. proteolyticus (D2 ${ }^{\mathrm{T}}$ and $\left.\mathrm{D} 6\right)$, D. radiodurans (D12 and D13), D. radiophilus $\left(\mathrm{D} 14^{\mathrm{T}}\right.$ and $\left.\mathrm{D} 16\right)$, D. radiopugnans $\left(\mathrm{D} 17^{\mathrm{T}}\right.$ and D18) and D. murrayi AG-3a ${ }^{\mathrm{T}}$ (Embley et al., 1987; Ferreira et al., 1997). The presence of PGL3, PL1 and GL5, the significantly larger amount of GL2 and the absence of certain other lipids clearly distinguished CCUG $53370^{\mathrm{T}}$ from its nearest relative as suggested by $16 \mathrm{~S}$ rRNA gene sequence similarity, Deinococcus ficus.

Respiratory quinones were extracted and analysed by HPLC as reported by Tindall (1990b) and Stolz et al. (2007). Strain CCUG $53370^{\mathrm{T}}$ contained a quinone system composed exclusively of menaquinone MK-8. This is in agreement with other Deinococcus species, which all contain menaquinone MK-8 as the major compound (Embley et al., 1987; Suresh et al., 2004; Ferreira et al., 1997; Lai et al., 2006).

Polyamines were extracted and analysed by HPLC as described in Busse \& Auling (1988) and Stolz et al. (2007). The polyamine pattern of strain CCUG $53370^{\mathrm{T}}$ consisted of the predominant component spermidine $[41.0 \mu \mathrm{mol}$ (g dry weight $\left.)^{-1}\right]$ and traces of spermine $[0.8 \mu \mathrm{mol}$ ( $\mathrm{g}$ dry weight $\left.)^{-1}\right]$, putrescine $\left[0.2 \mu \mathrm{mol}(\mathrm{g} \text { dry weight })^{-1}\right]$ and $1,3-$ diaminopropane $\left[0.2 \mu \mathrm{mol}(\mathrm{g} \text { dry weight })^{-1}\right]$. This polyamine pattern is in accordance with those of other deinococci, which were also reported to contain significant amounts of spermidine only in their polyamine patterns (Hamana, 1994).

The 16S rRNA gene was analysed as described by Kämpfer et al. (2003). Phylogenetic analysis was performed using the software package MEGA version 3.1 (Kumar et al., 2004) after multiple alignment of the data by CLUSTAL_X (Thompson et al., 1997). Distances were calculated (distance options according to the Kimura-2 model) and clustering with the neighbour-joining and maximumparsimony methods was performed by using bootstrap values based on 1000 replications. The almost-complete $16 \mathrm{~S}$ rRNA gene sequence of the strain was compared by sequence similarity calculations using the EzTaxon server (Chun et al., 2007). The results of these calculations indicated that the closest relatives of strain CCUG $53370^{\mathrm{T}}$ were $D$. ficus CC-FR2-10 $0^{\mathrm{T}}(94.4 \%), D$. navajonensis KR$114^{\mathrm{T}}(94.3 \%)$, Deinococcus mumbaiensis CON-1 ${ }^{\mathrm{T}}(94.3 \%)$ and D. radiodurans DSM $20539^{\mathrm{T}}(94.3 \%)$. All other Deinococcus species showed lower 16S rRNA gene sequence similarities. A phylogenetic tree is shown in Fig. 2. The 


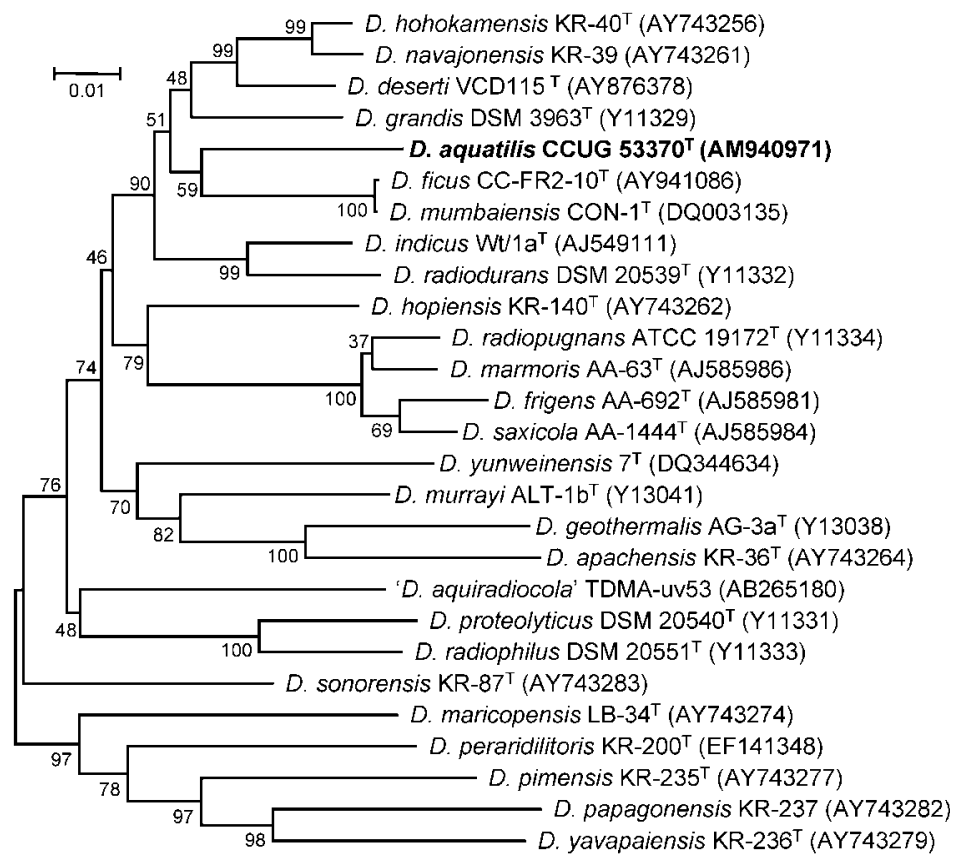

Fig. 2. Phylogenetic analysis based on $16 \mathrm{~S}$ rRNA gene sequences available from the EMBL database (accession numbers are given in parentheses) constructed after multiple alignments of data. Alignments, distance calculation (distance options according to the Kimura-2 model) and clustering with the neighbour-joining method were performed by using the software package MEGA version 3.1 (Kumar et al., 2004). Bootstrap values based on 1000 replications are listed as percentages at branching points. Bar, 0.01 substitution units $\left(K_{\text {nuc }}\right)$.

branching pattern was confirmed by maximum-parsimony analyses (data not shown). It should be noted here that $D$. ficus and D. mumbaiensis are very similar in both genotype and phenotype and seem to belong to the same species. On the basis of the results of this polyphasic taxonomic study, especially phylogenetic placement within the radiation of deinococci and the presence of characteristic polar lipids, menaquinone MK-8 and spermidine predominant in the polyamine pattern, it is clear that strain CCUG $53370^{\mathrm{T}}$ represents a novel species of the genus Deinococcus, for which the name Deinococcus aquatilis sp. nov. is proposed.

\section{Description of Deinococcus aquatilis sp. nov.}

Deinococcus aquatilis (a.qua.ti'lis. L. masc. adj. aquatilis living in water).

Cells stain Gram-positive and are non-motile, non-sporeforming rods. Aerobic and oxidase-positive. Good growth after $48 \mathrm{~h}$ on R2A agar, nutrient agar and tryptic soy agar at $15-36{ }^{\circ} \mathrm{C}$. Colonies on nutrient agar are smooth, pale pinkish, circular, translucent and shiny with entire edges, becoming mucoid. Unable to grow at 5 or $42{ }^{\circ} \mathrm{C}$. Growth occurs at $\mathrm{pH}$ 5.5-11. Major cellular fatty acids are $\mathrm{C}_{16: 1} \omega 7 c, \mathrm{C}_{17: 1} \omega 8 c$, iso- $\mathrm{C}_{17: 1} \omega 9 c, \mathrm{C}_{16: 0}$, iso- $\mathrm{C}_{17: 0}$ and $\mathrm{C}_{15: 1} \omega 6 c$. MK-8 is the predominant lipoquinone. Presents a complex polar lipid profile, consisting of different unidentified glycolipids and polar lipids, two unknown phospholipids and three unknown phosphoglycolipids, among them a predominant phosphoglycolipid with a migration on TLC similar to that of $2^{\prime}-O-(1,2-$ diacyl$s n$-glycero-3-phospho)-3'-O-( $\alpha$-galactosyl $)-N$-D-glyceroyl alkylamine, which has been identified in Deinococcus radiodurans. The polyamine pattern consists of the predominant component spermidine and traces of spermine, putrescine and 1,3-diaminopropane. The following compounds are utilized as sole carbon sources (positive after prolonged incubation for 14 days according to the method of Kämpfer et al., 1991): D-glucose, sucrose, $N$-acetyl-Dglucosamine, maltose and acetate. The following compounds are not utilized: D-gluconate, propionate, cis- and trans-aconitate, 4-aminobutyrate, citrate, fumarate, glutarate, DL-3-hydroxybutyrate, itaconate, DL-lactate, L-malate, mesaconate, 2 -oxoglutarate, pyruvate, L-alanine, $\beta$-alanine, L-aspartate, L-leucine, L-ornithine, L-proline, L-serine, $\mathrm{N}$ acetylgalactosamine, L-arabinose, L-arbutin, cellobiose, Dfructose, D-galactose, D-mannose, $\alpha$-melibiose, L-rhamnose, D-ribose, salicin, trehalose, $\mathrm{D}$-xylose, adonitol, myo-inositol, maltitol, D-mannitol, D-sorbitol, putrescine, adipate, azelate, suberate, L-histidine, L-phenylalanine, L-serine, L-tryptophan, 3-hydroxybenzoate and phenylacetate. bis- $p$ Nitrophenyl (pNP) phosphate, bis-pNP phenylphosphonate and bis-pNP phosphorylcholine are hydrolysed on the basis of the method described by Kämpfer et al. (1991). The following compounds are not hydrolysed: pNP $\beta$-Dgalactopyranoside, $\mathrm{pNP} \beta$-D-glucuronide, $\mathrm{pNP} \alpha$-D-glucopyranoside, pNP $\beta$-D-glucopyranoside, pNP $\beta$-D-xylopyranoside, $\mathrm{L}$-aniline $p$-nitroanilide (pNA), $\gamma$-L-glutamate pNA and L-proline pNA.

The type strain is CCUG $53370^{\mathrm{T}}\left(=\mathrm{CCM} 7524^{\mathrm{T}}\right)$, isolated from water.

\section{References}

Altenburger, P., Kämpfer, P., Makristathis, A., Lubitz, W. \& Busse, H.-J. (1996). Classification of bacteria isolated from a medieval wall painting. J Biotechnol 47, 39-52. 
Anderson, R. \& Hansen, K. (1985). Structure of a novel phosphoglycolipid from Deinococcus radiodurans. J Biol Chem 260, 12219-12223.

Asker, D., Awad, T. S., Beppu, T. \& Ueda, K. (2009). Deinococcus aquiradiocola sp. nov., isolated from a radioactive site in Japan. Int $J$ Syst Evol Microbiol 59 (in press).

Busse, H.-J. \& Auling, G. (1988). Polyamine pattern as a chemotaxonomic marker within the Proteobacteria. Syst Appl Microbiol 11, 1-8.

Callegan, R. P., Nobre, M. F., McTernan, P. M., Battista, J. R., NavarroGonzález, R., McKay, C. P., da Costa, M. S. \& Rainey, F. A. (2008). Description of four novel psychrophilic, ionizing radiation-sensitive Deinococcus species from alpine environments. Int $J$ Syst Evol Microbiol 58, 1252-1258.

Chun, J., Lee, J.-H., Jung, Y., Kim, M., Kim, S., Kim, B. K. \& Lim, Y. W. (2007). EzTaxon: a web-based tool for the identification of prokaryotes based on $16 \mathrm{~S}$ ribosomal RNA gene sequences. Int J Syst Evol Microbiol 57, 2259-2261.

de Groot, A., Chapon, V., Servant, P., Christen, R., Fischer-Le Saux, M., Sommer, S. \& Heulin, T. (2005). Deinococcus deserti sp. nov., a gammaradiation tolerant bacterium isolated from the Sahara desert. Int J Syst Evol Microbiol 55, 2441-2446.

Embley, T. M., O'Donnell, A. G., Watt, R. \& Rostron, J. (1987). Lipid and cell wall amino acid composition in the classification of members of the genus Deinococcus. Syst Appl Microbiol 10, 20-27.

Ferreira, A. C., Nobre, F. M., Rainey, F. A., Silva, M. T., Wait, R., Burghardt, J., Chung, A. P. \& Da Costa, M. S. (1997). Deinococcus geothermalis sp. nov. and Deinococcus murrayi sp. nov., two extremely radiation-resistant and slightly thermophilic species from hot springs. Int J Syst Bacteriol 47, 939-947.

Gerhardt, P., Murray, R. G. E., Wood, W. A. \& Krieg, N. R. (editors) (1994). Methods for General and Molecular Bacteriology. Washington, DC: American Society for Microbiology.

Hamana, K. (1994). Polyamine distribution patterns in aerobic Grampositive cocci and some radio-resistant bacteria. J Gen Appl Microbiol 40, 181-195.

Hirsch, P., Gallikowski, C. A., Siebert, J., Peissl, K., Kroppenstedt, R. M., Schumann, P., Stackebrandt, E. \& Anderson, R. (2004). Deinococcus frigens sp. nov., Deinococcus saxicola sp. nov., and Deinococcus marmoris sp. nov., low temperature and draughttolerating, UV-resistant bacteria from continental Antarctica. Syst Appl Microbiol 27, 636-645.

Kämpfer, P. \& Kroppenstedt, R. M. (1996). Numerical analysis of fatty acid patterns of coryneform bacteria and related taxa. Can J Microbiol 42, 989-1005.

Kämpfer, P., Steiof, M. \& Dott, W. (1991). Microbiological characterization of a fuel-oil contaminated site including numerical identification of heterotrophic water and soil bacteria. Microb Ecol 21, 227-251.

Kämpfer, P., Dreyer, U., Neef, A., Dott, W. \& Busse, H.-J. (2003). Chryseobacterium defluvii sp. nov., isolated from wastewater. Int J Syst Evol Microbiol 53, 93-97.

Kumar, S., Tamura, K. \& Nei, M. (2004). MEGA3: integrated software for molecular evolutionary genetics analysis and sequence alignment. Brief Bioinform 5, 150-163.

Lai, W.-A., Kämpfer, P., Arun, A. B., Shen, F.-T., Huber, B., Rekha, P. D. \& Young, C.-C. (2006). Deinococcus ficus sp. nov., isolated from the rhizosphere of Ficus religiosa L. Int J Syst Evol Microbiol 56, 787-791.

Rainey, F. A., Nobre, M. F., Schumann, P., Stackebrandt, E. \& Da Costa, M. S. (1997). Phylogenetic diversity of Deinococci as determined by $16 \mathrm{~S}$ ribosomal DNA sequence comparison. Int J Syst Bacteriol 47, 510-514.

Rainey, F. A., Ray, K., Ferreira, M., Gatz, B. Z., Nobre, M. F., Bagaley, D., Rash, B. A., Park, M.-J., Earl, A. M. \& other authors (2005). Extensive diversity of ionizing-radiation-resistant bacteria recovered from Sonoran Desert soil and description of nine new species of the genus Deinococcus from a single soil sample. Appl Environ Microbiol 71, 5225-5235.

Rainey, F. A., Ferreira, M., Nobre, M. F., Ray, K., Bagaley, D., Earl, A. M., Battista, J. R., Gómez-Silva, B., McKay, C. P. \& da Costa, M. S. (2007). Deinococcus peraridilitoris sp. nov., isolated from a coastal desert. Int J Syst Evol Microbiol 57, 1408-1412.

Shashidhar, R. \& Bandekar, J. R. (2006). Deinococcus mumbaiensis sp. nov., a radiation-resistant pleomorphic bacterium isolated from Mumbai, India. FEMS Microbiol Lett 254, 275-280.

Stolz, A., Busse, H.-J. \& Kämpfer, P. (2007). Pseudomonas knackmussii sp. nov. Int J Syst Evol Microbiol 57, 572-576.

Suresh, K., Reddy, G. S. N., Sengupta, S. \& Shivaji, S. (2004). Deinococcus indicus sp. nov., an arsenic-resistant bacterium from an aquifer in West Bengal, India. Int J Syst Evol Microbiol 54, 457-461.

Thompson, J. D., Gibson, T. J., Plewniak, F., Jeanmougin, F. \& Higgins, D. G. (1997). The CLUSTAL_X windows interface: flexible strategies for multiple sequence alignment aided by quality analysis tools. Nucleic Acids Res 25, 4876-4882.

Tindall, B. J. (1990a). Lipid composition of Halobacterium lacusprofundi. FEMS Microbiol Lett 66, 199-202.

Tindall, B. J. (1990b). A comparative study of the lipid composition of Halobacterium saccharovorum from various sources. Syst Appl Microbiol 13, 128-130.

Zhang, Y. Q., Sun, C. H., Li, W. J., Yu, L. Y., Zhou, J. Q., Zhang, Y. Q., Yu, L. H. \& Jiang, C. (2007). Deinococcus yunweiensis sp. nov., a gamma- and UV-radiation-resistant bacterium from China. Int J Syst Evol Microbiol 57, 370-375. 